J. Math. and Its Appl.

E-ISSN: 2579-8936

P-ISSN: 1829-605X

Vol. 14, No. 2, Desember 2017, 169-193

\title{
Penerapan Logika Fuzzy Dalam Memperkirakan Jumlah Produksi Telur Terhadap Permintaan Pasar
}

\author{
Anindita Nurizza Masquitasari Yusuf, Edy Widayat, Ahmad Hatip \\ Fakultas Keguruan dan Ilmu Pendidikan (FKIP), Universitas Dr. Soetomo Surabaya \\ ahmad.hatip@unitomo.ac.id
}

\begin{abstract}
The longer the population in Indonesia is growing, and making the number of egg demand also increases. Increasing demand to make a farm and egg distributor that is UD. Junjong Drajat in Bendiljet Orchard, Karangtalun Village, Kalidawir Subdistrict, Tulungagung District, there is often a problem in the supply of eggs due to poor inventory system and inaccurate determination of inventory. To solve the problem we require a system that can estimate the amount of egg production to be marketed on demand is using Fuzzy Logic Sugeno Method, because Sugeno method is able to classify data and customize with other data. The demand data patterns are trendy and seasonal so we use the Triple Exponensial Smoothing Additive Seasonal Method to predict the number of requests. The calculation results obtained forecasting the number of requests for April 30 to May 6, 2018 is $124.784 \mathrm{~kg}$, with parameters $\alpha=0,3, \beta=0,1$ and $\gamma=0,3$ has a MAPE (Mean Absolute Percentage Error) value of $26,57 \%$ Which is sufficient. For an estimated production amount using the Sugeno method of $87.800 \mathrm{~kg}$ (Toolbox Matlab), with a total inventory inventory of 79,200 kg.
\end{abstract}

Keywords : Exponential Smoothing, Fuzzy Logic, Demand of goods, Production of goods

\section{Pendahuluan}

Telur merupakan produk peternakan dan sumber protein hewani yang yang paling umum dikonsumsi oleh masyarakat. Namun, semakin lama penduduk di Indonesia semakin bertambah, dan membuat jumlah permintaan telur juga ikut bertambah. 
Menurut hasil pengamatan peneliti pada UD. Junjong Drajat di Dusun Bendiljet, Desa Karangtalun, Kecamatan Kalidawir, Kabupaten Tulungagung, sering terjadi masalah dalam penyediaan telur karena jumlah telur yang akan dipasarkan tidak sesuai dengan jumlah permintaan, sehingga hal ini sering menyebabkan kerugian.

Jadi, diperlukan suatu sistem yang dapat memperkirakan jumlah produksi telur yang akan dipasarkan sesuai permintaan dengan suatu metode tertentu. Salah satu metode yang dapat digunakan dalam memperkirakan jumlah produksi telur adalah dengan menggunakan logika fuzzy.

Peneliti menggunakan logika fuzzy metode Sugeno untuk memperkirakan jumlah produksi telur, karena mampu mengelompokkan data dan menyesuaikan dengan data yang lainnya. Selain itu konsep matematis yang mendasari penalaran fuzzy sangat sederhana serta mudah dimengerti sehingga tidak terlalu rumit untuk diterapkan pada permasalahan optimasi barang dengan data yang menunjukkan adanya trend dan bersifat musiman.

Peneliti juga menggunakan Pemulusan Eksponensial Tripel Holt-Winters Metode Penjumlahan, untuk memprediksi pemintaan pasar kedepan, karena data bersifat trend dan musiman sehingga metode ini lebih cocok untuk mengatasi data yang mengandung pola trend sekaligus musiman.

\subsection{Permasalahan}

Permasalahan yang dibahas dalam penelitian ini adalah bagaimanakah prediksi permintaan pasar dengan menggunakan metode Pemulusan Eksponensial Tripel Holt-Winters, bagaimanakah penerapan Logika fuzzy metode Sugeno dalam memperkirakan produksi telur terhadap prediksi permintaan pasar dan bagaimanakah prediksi permintaan pasar dan perkiraan produksi telur terhadap prediksi permintaan pasar untuk satu tahun mendatang.

\subsection{Tujuan}

Tujuan dari penelitian ini adalah memprediksi jumlah permintaan telur menggunakan metode Pemulusan Eksponensial Tripel Holt-Winters yang akan dipasarkan, menerapkan Logika Fuzzy metode Sugeno dalam 
memperkirakan jumlah telur dengan menggunakan logika fuzzy metode Sugeno terhadap prediksi permintaan pasar dan memprediksi permintaan pasar dan perkiraan produksi telur terhadap prediksi permintaan pasar untuk satu tahun mendatang. Peramalan khusus dilakukan di bulan April 2018 karena di Bulan April 2018 adalah masa hari raya Idul Fitri, yang mana permintaan akan telur sangatlah besar untuk kebutuhan konsumsi masyarakat.

\subsection{Manfaat}

Manfaat yang diharapkan dari penelitian ini adalah mengetahui prediksi jumlah permintaan telur yang akan dipasarkan untuk satu minggu kedepan, menggunakan metode Pemulusan Eksponensial Tripel Holt-Winters, mengetahui perkiraan jumlah produksi telur untuk satu minggu kedepan, menggunakan Logika Fuzzy khususnya metode Sugeno dan mengetahui prediksi jumlah permintaan pasar menggunakan metode Pemulusan Eksponensial Tripel Holt-Winters, dan mengetahui perkiraan jumlah produksi telur terhadap prediksi permintaan pasar menggunakan Logika fuzzy metode Sugeno, untuk satu tahun mendatang.

\subsection{Tinjauan Pustaka}

\section{Peramalan (Forecasting)}

Forecasting adalah peramalan (perkiraan) mengenai sesuatu yang akan terjadi pada waktu yang akan datang [5]. Menurut sifatnya, teknik peramalan terbagi menjadi dua jenis yaitu teknik kualitatif dan teknik kuantitatif. Metode peramalan kuantitatif dapat dibagi menjadi dua tipe, causal dan time series. Peramalan time series merupakan metode kuantitatif untuk menganalisis data masa lampau yang telah dikumpulkan secara teratur menggunakan teknik yang tepat. Hasilnya dapat dijadikan acuan untuk peramalan nilai di masa yang akan datang (Makridakis, 1999:8 dalam [4]). 


\section{Pola Data}

Menurut Lili Monika (2016 : 9-11), Hal penting yang harus diperhatikan dalam metode deret berkala adalah menentukan jenis pola dan historisnya, sehingga pola data yang tepat dengan pola data tersebut dapat diuji, pola data umumnya dapat dibedakan sebagai berikut :
A. Pola Horizontal
B. Pola Musiman
C. Pola Siklis
D. Pola Trend

\section{Metode Pemulusan Eksponensial Tripel}

Metode Pemulusan Eksponensial Tripel (Metode Holt-Winters) sering disebut metode pemulusan eksponensial yang melakukan pendekatan [6]. Metode ini terbagi menjadi dua bagian yakni :

\section{A. Metode Pemulusan Eksponensial Holt-Winters dengan Metode Perkalian Musiman (Mulplicative Seasonal Method)}

Pemulusan Keseluruhan

$$
S_{t}=\alpha \frac{X_{t}}{t_{t}-L}+(1-\alpha)\left(S_{t-1}+b_{t-1}\right)
$$

Pemulusan Trend

$$
b_{t}=\beta\left(S_{t}-S_{t-1}\right)+(1-\beta) b_{t-1}
$$

Pemulusan Musiman

$$
I_{t}=\gamma \frac{X_{t}}{s_{t}}+(1-\gamma) I_{t-L}
$$

Ramalan

$$
F_{t+m}=\left(S_{t}+m b_{t}\right) I_{t-L+m}
$$

Menentukan nilai awal pemulusan

$$
\begin{array}{r}
S_{L}=\frac{1}{L}\left(X_{1}+X_{2}+\ldots+X_{L}\right) \\
b_{L}=\frac{1}{L}\left(\frac{\left(x_{L+1}-X_{1}\right)+\left(x_{L+2}-X_{2}\right)+\ldots+\left(X_{L+L}-X_{L}\right)}{L}\right) \\
I_{K}=\frac{X_{K}}{S_{L}}
\end{array}
$$


B. Metode Pemulusan Eksponensial Holt-Winters dengan Metode

Penambahan Musiman (Additive Seasonal Method)

Pemulusan Keseluruhan

$$
S_{t}=\alpha\left(X_{t}-I_{t-L}\right)+(1-\alpha)\left(S_{t-1}+b_{t-1}\right)
$$

Pemulusan Trend

$$
b_{t}=\beta\left(S_{t}-S_{t-1}\right)+(1-\beta) b_{t-1}
$$

Pemulusan Musiman

$$
I_{t}=\gamma\left(X_{t}-S_{t}\right)+(1-\gamma) I_{t-L}
$$

Ramalan

$$
F_{t+m}=S_{t}+m b_{t}+I_{t-L+m}
$$

Menentukan nilai awal pemulusan

$$
\begin{gathered}
S_{L}=\frac{1}{L}\left(X_{1}+X_{2}+\ldots+X_{L}\right) \\
b_{L}=\frac{1}{L}\left(\frac{\left(X_{L+1}-X_{1}\right)+\left(X_{L+2}-X_{2}\right)+\ldots+\left(X_{L+L}-X_{L}\right)}{L}\right)(1.13) \\
I_{K}=X_{K}-S_{L}
\end{gathered}
$$

Makna simbol :

$$
\begin{array}{ll}
X_{t} & =\text { nilai aktual pada periode } \mathrm{ke}-\mathrm{t} \\
\alpha & =\text { konstanta penghalusan untuk data }(0<\alpha<1) \\
\beta & =\text { konstanta penghalusan untuk trend }(0<\beta<1) \\
\gamma & =\text { konstanta penghalusan untuk musiman }(0<\gamma<1) \\
S_{t} & =\text { nilai pemulusan awal } \\
b_{t} & =\text { konstanta pemulusan } \\
I & =\text { faktor penyesuaian musiman } \\
L & =\text { panjang musiman } \\
F_{t+m}=\text { ramalan } & \text { untuk } m \text { periode ke depan dari } t
\end{array}
$$




\section{Ukuran Akurasi Peramalan}

Menurut [8] model yang memiliki nilai kesalahan hasil peramalan terkecil yang akan dianggap sebagai model yang cocok, yaitu :

\section{A. Mean Squared Error (MSE)}

$$
\begin{aligned}
& S S E=\sum_{\mathrm{i}=1}^{\mathrm{n}} \mathrm{e}_{\mathrm{i}}^{2}=\sum_{\mathrm{i}=1}^{\mathrm{n}}\left(\mathrm{X}_{\mathrm{i}}-\mathrm{F}_{\mathrm{i}}\right)^{2} \quad \text { (1.15) } \\
& M S E=\frac{S S E}{n}=\sum_{i=1}^{n} \frac{\left(x_{\mathrm{i}}-F_{\mathrm{i}}\right)^{\mathrm{n}}}{n} \quad \text { (1.16) } \\
& \text { Dengan } \mathrm{X}_{\mathrm{i}} \text { adalah hasil sebenarnya di bulan/tahun } \\
& \text { sebelumnya dan } \mathrm{F}_{\mathrm{i}} \text { adalah nilai peramalan jumlah permintaan }
\end{aligned}
$$

\section{B. Mean Absolute Percentage Error (MAPE)}

Semakin kecil nilai MAPE yang didapat maka hasil ramalan tersebut semakin baik. Kriteria / kategori nilai MAPE (Chang, Wang \& Liu, 2007 dalam [1] ) :

- $<10 \%=$ Kemampuan peramalan sangat baik

- $10 \%-20 \%=$ Kemampuan peramalan baik

- $20 \%-50 \%=$ Kemampuan peramalan cukup

- $>50 \%=$ Kemampuan peramalan buruk

Namun, model yang tepat adalah model yang memiliki nilai MAPE sekitar $0 \%$ - $30 \%$. (Makridakis dalam [2])

Jadi, dapat disimpulkan nilai MAPE minimal cukup dan maksimal 30\% untuk dijadikan sebagai input dari metode Fuzzy.

Dirumuskan sebagai berikut :

$$
\begin{gathered}
P E_{t}=\left(\frac{x_{t}-F_{t}}{x_{t}}\right)(100) \\
M A P E=\sum_{i=1}^{n} \frac{\left|P E_{t}\right|}{n}
\end{gathered}
$$

\section{Logika Fuzzy}

\section{A. Himpunan Fuzzy}

Konsep tentang logika fuzzy diperkenalkan pada 1965 oleh Prof. Lotfi Astor Zadeh, seorang guru besar University of California USA. Himpunan fuzzy merupakan suatu kumpulan yang mewakili suatu kondisi atau keadaan 
tertentu dalam suatu variabel fuzzy. (Kusumadewi, 2002;21). Himpunan fuzzy memiliki 2 atribut, yaitu linguistik dan numeris.

\section{B. Fungsi Keanggotaan Fuzzy}

Fungsi keanggotaan (membership function) adalah suatu kurva yang menunjukkan pemetaan titik-titik input data kedalam nilai keanggotaan yang memiliki interval antara 0 sampai 1 . Ada beberapa fungsi yang bisa digunakan diantaranya ([3]) :

1) Representasi Linear

2) Representasi Kurva Segitiga

3) Representasi Kurva Trapesium

4) Representasi Kurva Bahu

\section{Sistem Inferensi Fuzzy}

Sistem ini berfungsi untuk mengambil keputusan melalui proses tertentu dengan mempergunakan aturan inferensi berdasarkan logika fuzzy. Dalam penelitian ini akan menggunakan metode Sugeno. Metode ini diperkenalkan oleh Takagi-Sugeno Kang pada tahun 1985. Untuk mendapatkan output (hasil), diperlukan 4 tahapan [7] :

1) Pembentukan himpunan fuzzy

Baik variabel input maupun variabel output dibagi menjadi satu atau lebih himpunan fuzzy. Dipergunakan untuk mengubah data masukkan tegas kedalam bentuk derajat keanggotaan.

2) Aplikasi fungsi implikasi

Fungsi implikasi yang digunakan untuk tiap - tiap aturan adalah fungsi $\min$.

$$
\mu\left(x_{i}\right)=\min \left(\mu_{s f}\left(x_{i}\right), \mu_{k f}\left(x_{i}\right)\right)
$$

Dengan :

$\mu_{s f}\left(x_{i}\right)=$ nilai keanggotaan solusi fuzzy sampai aturan ke $-\mathrm{i}$

$\mu_{k f}\left(x_{i}\right)=$ nilai keanggotaan konsekuen fuzzy aturan ke $-\mathrm{i}$ 
Aturan-aturan yang mungkin dan sesuai dengan fungsi implikasi ada 4 aturan (Solikin. F, 2011:63), yaitu :

[R.1] JIKA permintaan TURUN dan persediaan BANYAK, MAKA

$\left(\mathrm{Z}_{1}\right)$ Produksi Barang $=$ Permintaan - Persediaan

[R.2] JIKA permintaan TURUN dan persediaan SEDIKIT, MAKA

$\left(\mathrm{Z}_{2}\right)$ Produksi Barang $=$ Permintaan (1.21)

[R.3] JIKA permintaan NAIK dan persediaan BANYAK, MAKA

$\left(\mathrm{Z}_{3}\right)$ Produksi Barang $=$ Permintaan (1.22)

[R.4] JIKA permintaan NAIK dan persediaan SEDIKIT, MAKA

$\left(\mathrm{Z}_{4}\right)$ Produksi Barang $=(1,25 \mathrm{x}$ Permintaan $)-$ Persediaan

3) Komposisi aturan

Dalam melakukan inferensi sistem fuzzy metode Sugeno, menggunakan Probabilistic OR (probor). Rumus: [8]

$$
z_{i}, \mu_{A}\left(z_{i}\right)
$$

Keterangan :

$z_{i}=$ nilai keluaran pada aturan ke- $i$

$\mu_{\bar{A}}\left(z_{i}\right)=$ derajat keanggotaan nilai keluaran pada aturan ke- $i$

4) Penegasan (Defuzzyfikasi)

Untuk metode Sugeno dan metode Tsukamoto, secara umum untuk domain diskret dirumuskan (Solikin, F., 2011:42) :

$$
z^{*}=\mu(z)=\frac{\sum_{i=1}^{n} z_{i} \mu_{X}\left(z_{i}\right)}{\sum_{i=1}^{n} \mu_{\lambda}\left(z_{i}\right)}
$$

Keterangan :

$$
\begin{array}{ll}
z^{*} & =\text { nilai hasil defuzzifikasi } \\
\mu_{\tilde{A}}(z) & =\text { fungsi keanggotaan dari himpunan fuzzy } \\
\mathrm{z} & =\text { domain ke-i. }
\end{array}
$$

\section{METODE PENELITIAN}

2. 1 Pendekatan dan Jenis Penelitian 
Pendekatan penelitian yang digunakan dalam penelitian ini adalah pendekatan kualitatif dan jenis penelitian yang digunakan adalah penelitian deskriptif kualitatif.

\section{2 Data dan Sumber Data}

Data yang digunakan dalam penelitian ini adalah data primer (observasi dan wawancara) dan data sekunder (dokumen data produksi, data permintaan dan data persediaan). Sumber data penelitian ini adalah pimpinan UD. Junjong Drajat.

\section{3 Teknik Pengumpulan Data}

Teknik pengumpulan data yang digunakan dalam penelitian ini adalah wawancara, observasi (kondisi peternakan, pelaksanaan kerja, dll) dan dokumentasi (jumlah persediaan, produksi dan permintaan telur) dari tanggal 4 Januari 2016 - 30 April 2017.

\section{4 Tahap-tahap Penelitian}

\section{Pra Lapangan}

A. Menyusun rancangan penelitian berupa proposal

B. Lapangan penelitian yang digunakan dalam penelitian ini adalah UD. Junjong Drajat di Dsn. Bendiljet, Ds. Karangtalun, Kec. Kalidawir, Kab. Tulungagung.

\section{Tahap Pengumpulan Data}

A. Menetapkan jenis dan jumlah data yang akan digunakan yaitu 3 data sekunder (data jumlah permintaan per minggu, jumlah persediaan per minggu dan jumlah produksi telur per minggu).

B. Pengumpulan 3 data mingguan tersebut untuk satu tahun terakhir dalam hitungan berat ( $\mathrm{kg} /$ kilogram)

\section{Tahap Pengolahan Dan Perhitungan}

A. Peramalan jumlah permintaan telur (1 - 7 Mei 2017)

1) Mengetahui pola data (menentukan pola data permintaan dengan pola data sementara) 
2) Menentukan metode pemulusan eksponensial berdasarkan pola data

3) Perhitungan peramalan jumlah permintaan (menggunakan Pemulusan Eksponensial Tripel Holt-Winters Metode Penjumlahan) menggunakan MSE hingga mendapatkan nilai kesalahan yang paling kecil.

4) Menghitung error pada nilai peramalan dengan MAPE (minimal cukup untuk dijadikan sebagai input dari metode Fuzzy)

B. Penentuan jumlah produk (dengan input berupa perkiraan jumlah permintaan dan jumlah persediaan) dalam menentukan jumlah produk (1 - 7 Mei 2017) menggunakan Fuzzy metode Sugeno. (Solikin. F, 2011 : 56)

1) Pembentukan himpunan fuzzy

2) Aplikasi fungsi implikasi

3) Komposisi aturan

4) Penegasan (Defuzzyfikasi)

C. Peramalan permintaan telur dan perkiraan produksi telur untuk tanggal 30 April - 6 Mei 2018. Untuk meramalkan permintaan telur untuk tanggal 30 April - 6 Mei 2018 diperlukan data pada bulan yang sama di tahun sebelumnya yaitu diambil data tanggal 1-7 Mei 2017.

\section{HASIL DAN PEMBAHASAN}

Data sekunder yang didapat dari wawancara dan dokumen yang terkait dari UD. Junjong Drajat yaitu, data jumlah permintaan per minggu, jumlah persediaan per minggu dan jumlah produksi telur per minggu dalam satuan kg (kilogram) selama 1 tahun terakhir (Januari 2016 - April 2017), yang dimulai pada hari Senin.

Tabel 1. Data jumlah permintaan per minggu, jumlah persediaan per minggu dan jumlah produksi telur per minggu

\begin{tabular}{cccc}
\hline Tanggal & $\begin{array}{c}\text { Perm } \\
(\mathrm{kg})\end{array}$ & Prod (kg) & $\begin{array}{c}\text { Pers } \\
(\mathrm{kg})\end{array}$ \\
\hline 4-10 Jan '16 & 63.252 & 75.873 & 1.650 \\
\hline 11-17 Jan '16 & 71.200 & 67.695 & 14.271 \\
\hline 18-24 Jan '16 & 79.857 & 75.382 & 10.234 \\
\hline 25-31 Jan '16 & 59.471 & 67.537 & 5.759 \\
\hline 1-7 Feb '16 & 84.450 & 86.989 & 13.825 \\
\hline
\end{tabular}




\begin{tabular}{|c|c|c|c|}
\hline $8-14$ Feb ' 16 & 49.564 & 67.736 & 16.364 \\
\hline 15-21 Feb '16 & 51.698 & 68.328 & 34.536 \\
\hline Tanggal & Perm (kg) & Prod (kg) & Pers (kg) \\
\hline $22-28$ Feb ' 16 & 59.184 & 77.825 & 50.624 \\
\hline $29 \mathrm{Fe}-6$ Ma'16 & 46.050 & 81.832 & 67.695 \\
\hline 7-13 Mar ' 16 & 49.518 & 63.831 & 101.289 \\
\hline 14-20 Mar ' 16 & 63.268 & 78.618 & 114.508 \\
\hline 21-27 Mar '16 & 52.657 & 74.623 & 128.686 \\
\hline 28 Ма-3 Ар`16 & 59.035 & 85.573 & 149.257 \\
\hline 4-10 Apr ' 16 & 70.056 & 73.671 & 173.239 \\
\hline 11-17 Apr ' 16 & 49.750 & 8 & 175.499 \\
\hline 18-24 Apr ' 16 & 48.101 & 73.736 & 194.581 \\
\hline 25 Ар-1 Ме 16 & 93.668 & 87.431 & 219.012 \\
\hline 2-8 Mei '16 & 78.917 & 86.397 & 210.948 \\
\hline 9-15 Mei '16 & 99.990 & 85.831 & 218.428 \\
\hline 16-22 Mei '16 & 60.014 & 81.432 & 203.355 \\
\hline 23-29 Mei '16 & 76.279 & 86.325 & 222.849 \\
\hline $30 \mathrm{Me}-5 \mathrm{Jn}{ }^{`} 16$ & 61.200 & 75.212 & 231.640 \\
\hline 6-12 Jun' '16 & 50.090 & 80.223 & 244.992 \\
\hline 13-19 Jun '16 & 77.030 & 70.983 & 274.525 \\
\hline 20-26 Jun '16 & 67.108 & 69.643 & 267.690 \\
\hline 27Jun-3 Jul '16 & 50.346 & 69.378 & 269.099 \\
\hline 4-10 Jul '16 & 46.400 & 67.123 & 288.131 \\
\hline 11-17 Jul '16 & 106.883 & 87.429 & 308.036 \\
\hline 18-24 Jul '16 & 62.170 & 68.228 & 287.957 \\
\hline 25-31 Jul '16 & 124.190 & 7.369 & 291.894 \\
\hline 1-7 Agst' 16 & 96.806 & 81.835 & 255.073 \\
\hline 8-14 Agst ' 16 & 88.734 & 77.285 & 231.783 \\
\hline 15-21 Agst ' 16 & 109.541 & 78.768 & 213.168 \\
\hline $22-28$ Ags ' 16 & 103.077 & 78.635 & 182.395 \\
\hline $29 \mathrm{Ag}-4 \mathrm{Se}{ }^{\prime} 16$ & 118.476 & 86.872 & 157.953 \\
\hline 5-11 Sept ' 16 & 87.818 & 86.832 & 126.349 \\
\hline
\end{tabular}




\begin{tabular}{|c|c|c|c|}
\hline 12-18 Sept ' 16 & 94.005 & 82.893 & 125.363 \\
\hline 19-25 Sept ' 16 & 116.503 & 81.861 & 114.251 \\
\hline $26 \mathrm{Se}-2 \mathrm{Ok}{ }^{\prime} 16$ & 114.550 & 87.328 & 79.609 \\
\hline 3-9 Okt '16 & 121.000 & 69.383 & 50.737 \\
\hline 10-16 Okt '16 & 110.400 & 72.992 & 4.070 \\
\hline 17-23 Okt '16 & 124.270 & 87.375 & 6.262 \\
\hline 24-30 Okt' 16 & 114.270 & 84.979 & 4.017 \\
\hline $31 \mathrm{Ok}-6 \mathrm{Nv}^{6} 16$ & 145.886 & 84.137 & 4.426 \\
\hline $7-13$ Nov'16 & 69.909 & 80.328 & 2.077 \\
\hline 14-20 Nov' 16 & 48.885 & 81.832 & 11.121 \\
\hline 21-27 Nov' 16 & 59.295 & 87.434 & 42.918 \\
\hline $28 \mathrm{Nv}-4 \mathrm{De}^{6} 16$ & 72.518 & 79.783 & 69.399 \\
\hline 5-11 Des '16 & 48.830 & 84.872 & 75.914 \\
\hline 12-18 Des '16 & 65.055 & 85.573 & 111.236 \\
\hline 19-25 Des '16 & 96.050 & 78.365 & 124.504 \\
\hline 26 D‘16-1 J'17 & 92.400 & 86.998 & 106.819 \\
\hline 2-8 Jan '17 & 83.950 & 84.855 & 101.417 \\
\hline 9-15 Jan' 17 & 70.097 & 79.818 & 102.322 \\
\hline 16 - 22 Jan' 17 & 98.328 & 83.832 & 111.220 \\
\hline $23-29$ Jan ' 17 & 74.128 & 83.623 & 95.615 \\
\hline Tanggal & Perm (kg) & Prod (kg) & Pers (kg) \\
\hline $30 \mathrm{Ja}-5 \mathrm{Fe}^{`} 17$ & 48.410 & 78.973 & 105.110 \\
\hline 6-12 Feb'17 & 106.440 & 83.738 & 135.673 \\
\hline $13-19$ Feb '17 & 78.015 & 84.639 & 112.971 \\
\hline $20-26$ Feb '17 & 79.320 & 83.736 & 119.595 \\
\hline $27 \mathrm{Fe}-5 \mathrm{Ma}$ ' 17 & 71.310 & 84.861 & 124.011 \\
\hline 6-12 Mar ' 17 & 71.700 & 84.695 & 137.562 \\
\hline 13-19 Mar '17 & 70.200 & 83.367 & 150.557 \\
\hline $20-26$ Mar '17 & 113.275 & 83.328 & 162.674 \\
\hline 27 Ма-2 Аp'17 & 120.040 & 84.827 & 132.727 \\
\hline 3-9 Apr '17 & 133.130 & 85.832 & 96.914 \\
\hline $10-16$ Apr '17 & 74.445 & 82.825 & 49.616 \\
\hline
\end{tabular}




\begin{tabular}{cccc}
\hline 17-23 Apr '17 & 97.905 & 85.291 & 57.996 \\
\hline 24-30 Apr '17 & 73.428 & 86.387 & 45.382 \\
\hline $\mathbf{1 - 7}$ Mei '17 & $?$ & $?$ & 58.341 \\
\hline
\end{tabular}

\section{1 Peramalan Jumlah Permintaan Mengetahui Pola Data}

Untuk lebih mudah menetukan pola data, dapat dilakukan penentuan pola data sementara

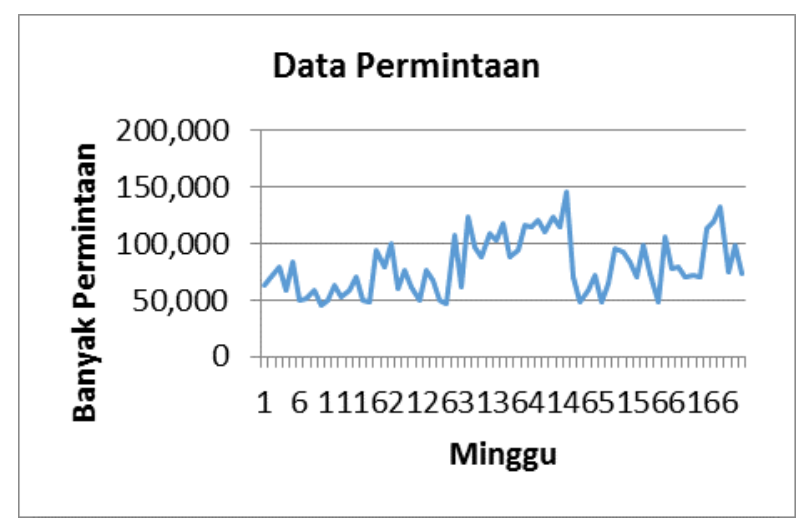

Gambar 1. Time Series Plot Jumlah Permintaan

Jumlah permintaan pada periode ke-27 hingga periode ke-45 cenderung naik, ke-47 hingga periode ke-65 cenderung naik lagi. Pada gambar juga terlihat jumlah permintaan yang naik-turun pada periode-periode tertentu sehingga dapat disimpulkan bahwa pola data sementara yang diperoleh sesuai dengan data trend dan musiman.

\section{A. Menentukan Metode Pemulusan Eksponensial Berdasarkan Pola Data}

Berdasarkan pola data yang diperoleh maka metode peramalan yang cocok untuk pola data trend dan musiman adalah metode Pemulusan Eksponensial Tripel Holt-Winters dengan Metode Penambahan Musiman karena lebih efektif dalam data trend dan musiman dengan variasi musiman yang bersifat konstan.

\section{B. Perhitungan Peramalan Jumlah Permintaan}

Menentukan parameter dengan nilai MSE (Mean Squared Error) terkecil, dengan cara mengambil $\alpha, \beta$ dan $\gamma$ sembarang dalam rentang 0 sampai 1. Langkah-langkah perhitungan sebagai berikut : 
1) Menentukan nilai awal dengan 12 data aktual awal (4 Januari - 27 Maret 2016)

$$
\begin{aligned}
S_{L}=\frac{1}{L}\left(X_{1}+X_{2}+\ldots+X_{L}\right) \\
S_{12}=\frac{1}{12}\left(\begin{array}{c}
63.252+71.200+79.857+59.471 \\
+84450+49.564+51.698+59.184 \\
+46.050+49.518+63.268+52.657
\end{array}\right) \\
S_{12}=60.847,64
\end{aligned}
$$

2) Menghitung Peramalan Jumlah Permintaan

$$
\begin{aligned}
& F_{t+m}=S_{t}+m b_{t}+I_{t-L+m} \\
& F_{12+1}=S_{12}+1 \cdot b_{12}+I_{12-12+1} \\
& F_{1 a}=60.847,42+1(652,51)+2.404,58 \\
& F_{1 \mathrm{a}}=63.905 \\
& \mathrm{~m}=1 \text { karena data permintaan yang akan diramal adalah } 1 \text { periode } \\
& \text { mendatang }
\end{aligned}
$$

Dengan parameter $\alpha=0,1, \beta=0,1$ dan $\gamma=0,1$, menghasilkan peramalan untuk tanggal $1-7$ Mei 2017 sebagai berikut : 
Tabel 2. Data peramalan jumlah permintaan dengan

\begin{tabular}{|c|c|c|c|c|}
\hline $\mathrm{Mgu}$ & $S_{t}$ & $b_{t}$ & $I_{t}$ & $F_{t+m}$ \\
\hline 12 & $60.847,42$ & 652,51 & $-8.190,42$ & \\
\hline 13 & $61.012,97$ & 603,81 & $1.966,33$ & 63.905 \\
\hline 14 & $61.425,45$ & 584,68 & $10.180,38$ & 71.969 \\
\hline 15 & $58.883,16$ & 271,98 & $16.195,31$ & 81.020 \\
\hline$\vdots$ & $\vdots$ & $\vdots$ & $\vdots$ & $\vdots$ \\
\hline 35 & $95.358,39$ & $2.182,15$ & $2.368,13$ & 92.859 \\
\hline 36 & $97.269,98$ & $2.155,09$ & $-7.260,44$ & 90.524 \\
\hline Mgu & $\overline{S_{t}}$ & $\overline{b_{t}}$ & $I_{t}$ & $F_{t+m}$ \\
\hline 37 & $98.771,09$ & $2.089,69$ & 531,11 & 100.545 \\
\hline$\vdots$ & $\vdots$ & $\vdots$ & $\vdots$ & $\vdots$ \\
\hline 67 & $84.536,15$ & $-226,33$ & $-2.134,54$ & 84.268 \\
\hline 68 & $85.662,17$ & $-91,10$ & $1.288,83$ & 84.382 \\
\hline 69 & $85.881,19$ & $-60,09$ & $-14.965,17$ & 70.327 \\
\hline 70 & \multicolumn{3}{|c|}{ Jumlah Ramalan Permintaan } & $74.805 \mathrm{~kg}$ \\
\hline
\end{tabular}

3) Perhitungan MSE (Mean Squared Error)

$$
\begin{aligned}
& \text { SSE }=\sum_{i=1}^{n} e_{i}^{2}=\sum_{i=1}^{n}\left(X_{i}-F_{i}\right)^{2} \\
& =46.827 \cdot 213.630,97 \\
& \text { MSE }=\frac{\text { SSE }}{n}=\frac{46.827 .213 .630,97}{57}
\end{aligned}
$$

$=821.530 .063,70$

Karena hasil MSE dengan $\alpha=0,1, \beta=0,1$ dan $\gamma=0,1$ tersebut belum tentu hasil dengan kesalahan yang paling kecil, maka diperlukan perhitungan MSE kembali, dengan $\alpha, \beta$ dan $\gamma$ yang lain dalam rentang $0-1$.

Perhitungan MSE dengan cara Trial and Error serta bantuan Ms. Excel didapatkan MSE yang paling kecil adalah pada nilai peramalan dengan parameter $\alpha=0,3, \beta=0,1$ dan $\gamma=0,3$ adalah 84.088,39 dengan MSE sebesar 703.562.699,89. 
Tabel 3. Data peramalan jumlah permintaan dengan parameter $\alpha=0,3, \beta=0,1$ dan $\gamma=0,3$

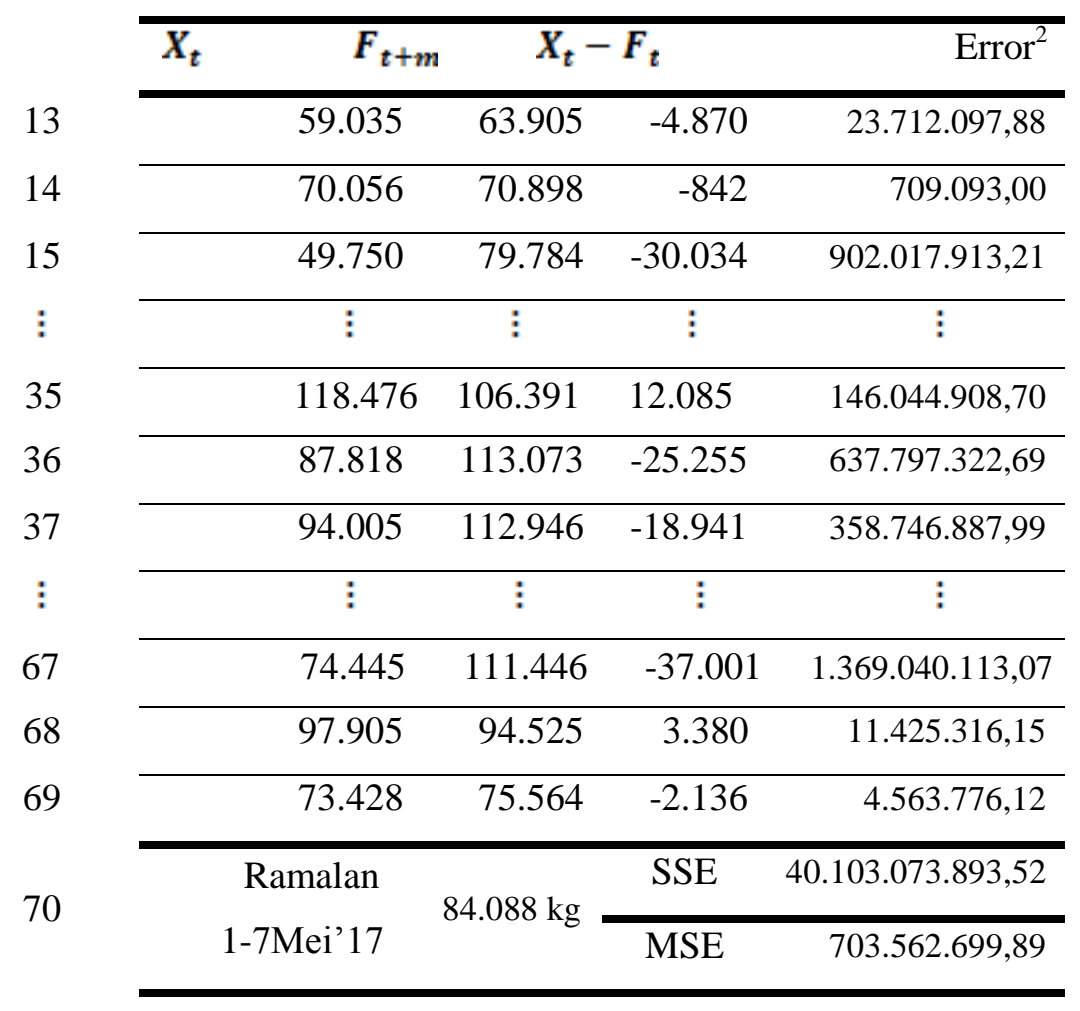

4) Menghitung Error pada nilai peramalan dengan MAPE

Perhitungan MAPE pada peramalan dengan parameter $\alpha=0,3$, $\beta=0,1$ dan $\gamma=0,3$

Tabel 4. Hasil perhitungan MAPE pada ramalan jumlah permintaan telur

\begin{tabular}{|c|c|c|c|c|c|}
\hline$\overline{\mathrm{Mgu}}$ & $\overline{X_{t}}$ & & $\overline{F_{t+m}}$ & $\overline{P E_{t}}$ & $\overline{\left|P E_{t}\right|}$ \\
\hline 13 & 59.035 & & 63.905 & $-8,25$ & 8,25 \\
\hline 14 & 70.056 & & 70.898 & $-1,20$ & $\overline{1,20}$ \\
\hline 15 & 49.750 & & 79.784 & $-60,37$ & 60,37 \\
\hline $\bar{\vdots}$ & $\bar{\vdots}$ & $\bar{\vdots}$ & $\bar{\vdots}$ & & \\
\hline 35 & 118.476 & & 106.391 & 10,20 & 10,20 \\
\hline 36 & 87.818 & & 113.073 & $-28,76$ & 28,76 \\
\hline 37 & 94.005 & & 112.946 & $-20,15$ & 20,15 \\
\hline $\bar{\vdots}$ & $\bar{\vdots}$ & & $\bar{\vdots}$ & $\bar{\vdots}$ & $\begin{array}{l}\vdots \\
\vdots\end{array}$ \\
\hline 67 & 74.445 & & 111.446 & $-49,70$ & 49,70 \\
\hline
\end{tabular}




\begin{tabular}{lllll}
\hline 68 & 97.905 & 94.525 & 3,45 & 3,45 \\
\hline 69 & 73.428 & 75.564 & $-2,91$ & 2,91 \\
\hline 70 & Ramalan & $84.088 \mathrm{~kg}$ & & \\
& $1-7$ Mei' 17 & & & \\
\hline \multicolumn{5}{c}{ Total $\left|\boldsymbol{P} \boldsymbol{E}_{\boldsymbol{t}}\right|$} \\
\end{tabular}

MAPE $=\sum_{i=1}^{n} \frac{\left|P E_{\mathrm{t}}\right|}{n}=\frac{1.514,36}{57}=26,57$

Berdasarkan perhitungan nilai MAPE dari periode ke-13 sampai dengan periode ke-69 sebesar 26,57\% sehingga nilai ramalan untuk periode ke-70 (1 - 7 Mei 2017) tergolong cukup dan memenuhi syarat, karena < 30\%. Oleh karena itu, nilai peramalan permintaan tersebut dapat digunakan sebagai input pada metode Sugeno.

\section{Penentuan Jumlah Produk}

Dari data pada Tabel 1, dapat disimpulkan, jika data permintaan terbanyak adalah $145.886 \mathrm{~kg}$ perminggu, dan permintaan terkecil adalah $46.050 \mathrm{~kg}$ perminggu. Persediaan telur terbanyak adalah $308.036 \mathrm{~kg}$ perminggu, dan persediaan minimal adalah $1.500 \mathrm{~kg}$ perminggu. Sedangkan produksi telur saat ini maksimal $87.500 \mathrm{~kg}$ perminggu, dan produksi minimal $61.250 \mathrm{~kg}$ perminggu. Sedangkan persediaan untuk tanggal $1-7$ Mei 2017 adalah $58.341 \mathrm{~kg}$, serta peramalan permintaan telur sebesar $84.088 \mathrm{~kg}$.

1) Pembentukan Himpunan Fuzzy

Banyaknya variabel dalam pengambilan keputusan produksi telur ada 3 macam, masing-masing variabel mempunyai 2 nilai linguistik, yaitu :

a) Untuk PERMINTAAN, nilai linguistiknya TURUN dan NAIK.

b) Untuk PERSEDIAAN, nilai linguistiknya SEDIKIT dan BANYAK.

c) Untuk PRODUKSI telur, nilai linguistiknya BERKURANG dan BERTAMBAH.

Fuzzifikasi variabel permintaan 
Permintaan terbanyak mencapai $145.886 \mathrm{~kg}$ perminggu, dan permintaan terkecil adalah $46.050 \mathrm{~kg}$ perminggu dan diketahui peramalan permintaan telur sebesar $84.088 \mathrm{~kg}$, maka:

$$
\begin{aligned}
& \mu_{\text {pmitTurun }}(84.088)=\frac{145.986-84.089}{145.986-46.050}=\frac{61.798}{99.926}=0,62 \\
& \mu_{\text {pmitNaik }}(84.088)=\frac{84.089-58.495}{145.986-46.050}=\frac{98.038}{99.926}=0,38
\end{aligned}
$$
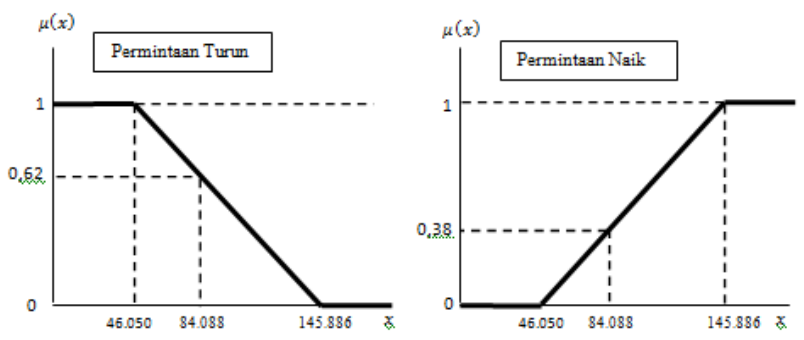

Gambar 3.2 Grafik Permintaan Turun dan

$$
\text { Permintaan Naik }
$$

Fuzzifikasi variabel persediaan

Persediaan telur terbanyak adalah $308.036 \mathrm{~kg}$ perminggu, dan persediaan minimal adalah $1.500 \mathrm{~kg}$ perminggu dan diketahui persediaan untuk tanggal 1 - 7 Mei 2017 adalah $58.341 \mathrm{~kg}$, maka :

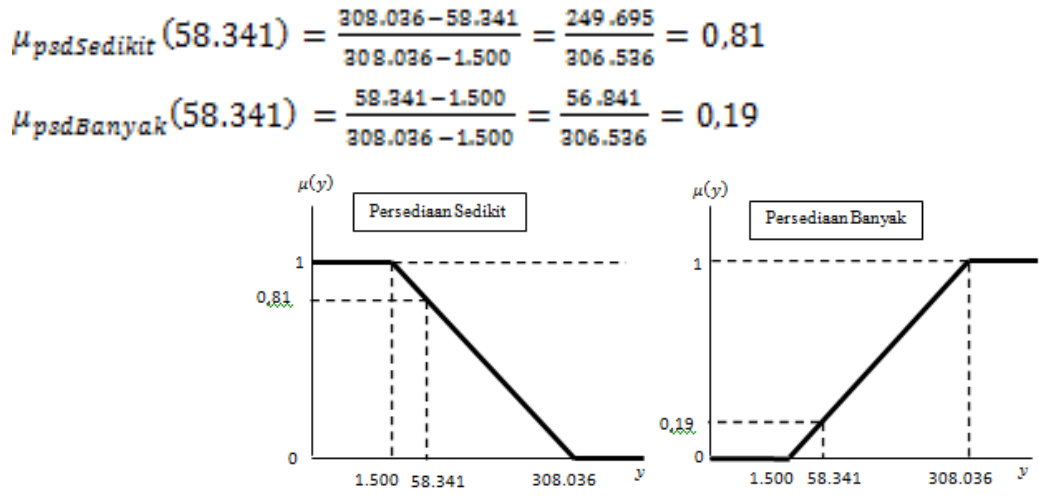

Gambar 3. Grafik Persediaan Sedikit dan

Persediaan Banyak

Fuzzifikasi variabel produksi

Peternakan memproduksi telur tersebut maksimum $87.500 \mathrm{~kg}$ perminggu, dan produksi paling sedikit $61.250 \mathrm{~kg}$ perminggu. 

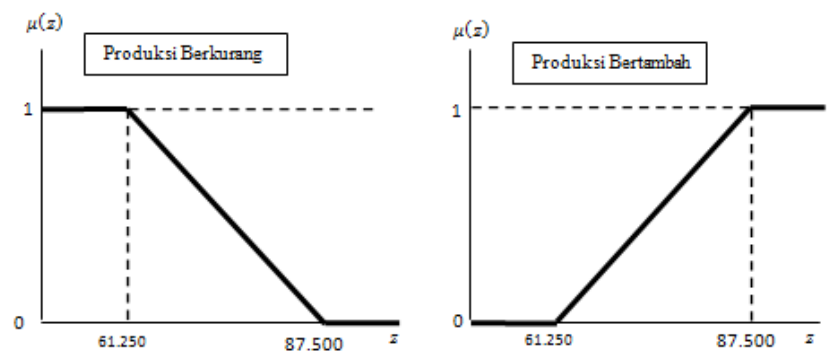

Gambar 4. Grafik Produksi Berkurang dan

Produksi Bertambah

2) Aplikasi Fungsi Implikasi

Berdasarkan dari pembentukan himpunan fuzzy maka aturan-aturan yang mungkin dan sesuai ada 4 aturan, yaitu :

Tabel 5. Kesimpulan dari aturan-aturan dari contoh aplikasi metode Sugeno

\begin{tabular}{ccccc}
\hline Aturan & Perm & Pers & $\begin{array}{c}\text { Fungsi } \\
\text { Implikasi }\end{array}$ & Prod \\
\hline R.1 & Turun & Sedikit & $\Rightarrow$ & Berkurang \\
\hline R.2 & Turun & Banyak & $\Rightarrow$ & Berkurang \\
\hline R.3 & Naik & Sedikit & $\Rightarrow$ & Bertambah \\
\hline R.4 & Naik & Banyak & $\Rightarrow$ & Bertambah \\
\hline
\end{tabular}

Aplikasi fungsi implikasi untuk R.1

Derajat keanggotaan

$\mu\left(z_{1}\right)=\min$

$$
\left\{\mu_{\text {pmtTrn }}(84.088), \mu_{\text {psdSdt }}(58.341)\right\}
$$

$=\min \{0,62 ; 0,81\}$

$=0,62$

$z_{1}=$ Permintaan $=84.088$

Aplikasi fungsi implikasi untuk R.2

Derajat keanggotaan

$\mu\left(z_{2}\right)=\min$

$\left\{\mu_{\text {pmtTrn }}(84.088), \mu_{\text {psdByk }}(58.341)\right\}$

$=\min \{0,62 ; 0,19\}$ 


$$
\begin{aligned}
& =0,19 \\
z_{2} & =\text { Permintaan }- \text { Persediaan } \\
& =84.088-58.341 \\
& =25.747
\end{aligned}
$$

Aplikasi fungsi implikasi untuk R.3

Derajat Keanggotaan

$$
\begin{aligned}
& \mu\left(z_{3}\right)= \min \\
&\left\{\mu_{\text {pmtNaik }}(84.088), \mu_{\text {psdSdt }}(58.341)\right\} \\
&= \min \{0,38 ; 0,81\} \\
&= 0,38 \\
& z_{3} \quad=(1,25 . \text { Permintaan })-\text { Persediaan } \\
&=(1,25(84.088))-58.341 \\
&=105.110-58.341 \\
&=46.769
\end{aligned}
$$

Aplikasi fungsi implikasi untuk R.4

Derajat Keanggotaan

$$
\begin{aligned}
\mu\left(z_{4}\right)= & \min \\
& \left\{\mu_{\text {pmitNaik }}(86.421,66), \mu_{\text {padByk }}(12.934)\right\} \\
= & \min \{0,38 ; 0,19\} \\
= & 0,19 \\
z_{4} \quad= & \text { Permintaan }=84.088
\end{aligned}
$$


3) Komposisi Aturan

Hasil perkalian tiap aturan adalah

$$
\begin{aligned}
& z_{1} \cdot \mu_{A}\left(z_{1}\right)=84.088 \times 0,62=52.134,56 \\
& z_{2} \cdot \mu_{\pi}\left(z_{2}\right)=25.747 \times 0,19=4.891,93 \\
& z_{3} \cdot \mu_{A}\left(z_{3}\right)=46.769 \times 0,38=17.772,22 \\
& z_{4} \cdot \mu_{A}\left(z_{4}\right)=84.088 \times 0,19=15.976,72
\end{aligned}
$$

4) Penegasan (Defuzzyfikasi)

$$
z^{*}=\mu(z)=\frac{\sum_{i=1}^{n} z_{i} \mu_{\tilde{A}}\left(z_{i}\right)}{\sum_{i=1}^{n} \mu_{\tilde{A}}\left(z_{i}\right)}
$$

Perhitungan :

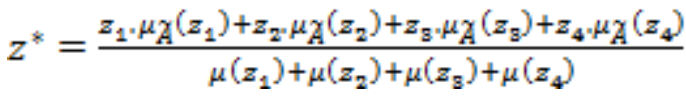

$$
\begin{aligned}
& =\frac{52.134,56+4,891,93+17.772,22+15,976,72}{0,62+0,19+0,38+0,19} \\
& =\frac{90.775,43}{1,38} \\
& =65.779
\end{aligned}
$$

Jadi, jumlah telur yang harus diproduksi sebanyak $65.779 \mathrm{~kg}$ telur.

Setelah dilakukan pengolahan data dengan menggunakan metode Sugeno dengan perhitungan manual dan metode Sugeno menggunakan Toolbox Matlab , maka didapatkan output berupa produksi barang.

Tabel 6. Data produksi telur pada tanggal $1-7$ Mei 2017 melalui perhitungan manual dan Toolbox Matlab
Input
Output (Produksi)

Tgl

Ramalan

Permintaan

Persediaan

Manual

Matlab

\begin{tabular}{lllll}
\hline $1-7$ Mei 2017 & $84.088 \mathrm{~kg}$ & $58.341 \mathrm{~kg}$ & $65.779 \mathrm{~kg}$ & $65.800 \mathrm{~kg}$ \\
\hline
\end{tabular}

Hasil perhitungan relatif sama, karena perbedaan tidak besar. Perbedaan tersebut dikarena pada Toolbox Matlab terjadi beberapa pembulatan, sehingga output yang dihasilkan sedikit berbeda. 
Selanjutnya, peneliti melakukan peramalan permintaan untuk tanggal 30 April - 6 Mei 2018 dengan parameter yang sama yaitu $=0,3, \beta=0,1$ dan $\gamma=0,3$ (rumus dan cara yang sama), dengan permisalan persediaan $79.200 \mathrm{~kg}$, serta peramalan produksi menggunakan Toolbox Matlab.

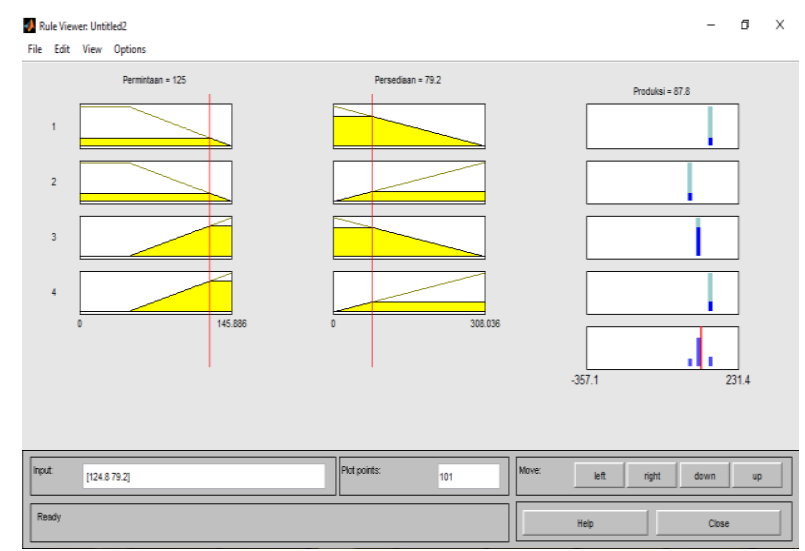

Gambar 5. Penegasan (Defuzzyfikasi) dengan MATLAB

Tabel 7. Data peramalan permintaan dan perkiraan produksi telur pada tanggal 30 April -6 Mei 2018 melalui perhitungan manual dan Toolbox Matlab

\begin{tabular}{ccccc}
\hline & \multicolumn{2}{c}{ Input } & Output (Produksi) \\
\hline Tgl & Ramalan & Psd & Manual & Matlab \\
& Perm & & & \\
\hline $30 \mathrm{Ap}-$ & $124.784 \mathrm{~kg}$ & $79.200 \mathrm{~kg}$ & $87.717 \mathrm{~kg}$ & $87.800 \mathrm{~kg}$ \\
6 Mei 2018 & & & & \\
\hline
\end{tabular}

\section{Pembahasan Hasil Penelitian}

Data hasil peramalan jumlah permintaan, serta output Toolbox Matlab pada data UD. Junjong Drajat dari tanggal 10 April - 7 Mei 2017, serta tanggal 30 April - 6 Mei 2018 adalah sebagai berikut :

Tabel 8. Data hasil peramalan melalui perhitungan manual dan Toolbox Matlab

\begin{tabular}{|c|c|c|c|c|c|c|}
\hline & \multicolumn{2}{|c|}{ Input } & \multicolumn{4}{|c|}{ Output (Produksi) } \\
\hline Tanggal & $\begin{array}{l}\text { Perm } \\
(\mathrm{kg})\end{array}$ & $\begin{array}{l}\text { Ramal } \\
\text { Perm } \\
(\mathrm{kg})\end{array}$ & $\begin{array}{l}\text { Psd } \\
(\mathrm{kg})\end{array}$ & $\begin{array}{l}\text { Prod } \\
(\mathrm{kg})\end{array}$ & $\begin{array}{c}\text { Prod } \\
\text { Manual }\end{array}$ & $\begin{array}{c}\text { Matlab } \\
(\mathrm{kg})\end{array}$ \\
\hline 10-16 Ap’17 & 74.445 & 111.446 & 49.616 & 82.825 & 61.854 & 61.800 \\
\hline
\end{tabular}




\begin{tabular}{lllllll}
\hline 17-23 Ap'17 & 97.905 & 94.525 & 57.996 & 85.291 & 77.413 & 77.400 \\
\hline 24-30 Ap'17 & 73.428 & 75.564 & 45.382 & 86.387 & 62.764 & 62.600 \\
\hline 1-7 Mei'17 & 78.710 & 84.088 & 58.341 & 74.442 & 65.779 & 65.800 \\
\hline 8-14 Mei’17 & 95.527 & 84.747 & 54.073 & 83.909 & 74.775 & 74.900 \\
\hline 30 Ap-6 Mei'18 & & $124.784 \mathrm{~kg}$ & $79.200 \mathrm{~kg}$ & & $87.717 \mathrm{~kg}$ & 87.800 \\
\hline
\end{tabular}

\section{Kesimpulan dan Saran}

\subsection{Kesimpulan}

1) Prediksi permintaan pasar dengan menggunakan metode pemulusan eksponensial tripel Holt-Winters untuk tanggal 1 - 7 Mei 2017 adalah 84.088 $\mathrm{kg}$, dengan parameter $\alpha=0,3, \beta=0,1$ dan $\gamma=0,3$ mempunyai nilai MAPE (Mean Absolute Percentage Error) 26,57 \% yang tergolong cukup dan memenuhi syarat karena $<30 \%$.

2) Penerapan dari metode Fuzzy Sugeno menggunakan metode Centroid pada tanggal $1-7$ Mei 2017 dengan ramalan permintaan telur $84.088 \mathrm{~kg}$ dan persediaan telur sebesar $58.341 \mathrm{~kg}$, menghasilkan perhitungan perkiraan produksi telur, secara manual sebesar $65.824 \mathrm{~kg}$, dan dengan Toolbox Matlab sebesar $65.800 \mathrm{~kg}$, sedangkan produksi aktualnya adalah $74.442 \mathrm{~kg}$.

3) Prediksi permintaan untuk tanggal 30 April -6 Mei 2018 dengan parameter yang sama $\alpha=0,3, \beta=0,1$ dan $\gamma=0,3$, menghasilkan ramalan sebesar $124.784 \mathrm{~kg}$, dengan permisalan jumlah persediaan $79.200 \mathrm{~kg}$, menghasilkan ramalan produksi sebesar $87.800 \mathrm{~kg}$ (Toolbox Matlab).

\subsection{Saran}

1) Variabel persediaan perlu diperhitungkan distributor maupun pengusaha lainnya, karena persediaan berpengaruh besar dalam optimasi jumlah produksi.

2) Peramalan jumlah permintaan serta perhitungan produksi dapat menggunakan metode lain dengan data masa lalu yang lebih banyak. 
3) Dapat menjadikan metode Sugeno serta memanfaatkan Toolbox Matlab sebagai salah satu alternatif panduan dalam penyusunan produksi, dengan harapan metode ini lebih efektif daripada menggunakan metode manual perusahaan.

4) Dapat mempelajari dan lebih mendalami lagi teori tentang logika fuzzy dan penerapannya dalam permasalahan sehari-hari.

\section{Daftar Pustaka}

[1] Halimi. R, dkk. 2013. "Pembuatan Aplikasi Peramalan Jumlah Permintaan Produk Dengan Metode Time Series Exponential Smothing Holts Winter Di PT. Telekomunikasi Indonesia Tbk”. Jurnal Teknik POMITS Vol. 1, No. 1, hal : 1 - 6. Surabaya : Institut Teknologi Sepuluh November

[2] Heriyani, dkk. 2015. "Peramalan Jumlah Penduduk Dengan Metode Trend Non Linier". Jurnal EKSPONENSIAL Vol. 6, No. 1, hal : 95 100. http:www.google.com. 27 Juli 2017.

[3] Kusumadewi, Sri., Sri H., Agus H., \& Retyanto W. 2006. Fuzzy MultiAttribute Decision Making (FUZZY MADM). Yogyakarta : Graha Ilmu.

[4] Monika, Lili. 2016. "Metode Pemulusan Eksponensial Ganda Dengan Verifikasi Pemantauan Tracking Signal Pada Data Tingkat Inflasi Di Indonesia Tahun 2011-2015”. Skripsi. Universitas Islam Negeri Maulana Malik Ibrahim. Malang

[5] Subagyo, Pangestu. 1986. Forecasting Konsep dan Aplikasi. BPFE Yogyakarta. Yogyakarta

[6] Padang .E, Gim T. dan Ujian S. 2013. "Peramalan Jumlah Penumpang Kereta Api Medan-Rantau Prapat Dengan Metode Pemulusan 
Eksponensial Holt-Winters". Saintia Matematika, Vol. 1, No. 2, hal : 161 - 174. Medan : University of Sumatera Utara

[7] Solikin, Fajar. 2011. Aplikasi Logika Fuzzy Dalam Optimasi Produksi Barang Menggunakan Metode Mamdani Dan Metode Sugeno. Skripsi. Universitas Negeri Yogyakarta

[8] Suwandi, Adi, dkk. 2014. Peramalan Data Time Series dengan Metode Penghalusan Eksponensial Holt-Winter. http:www.google.com. 30 Mei 2017. 